\title{
COVID-19 Viral Logics, Social Inequality and Hegemonic Mimicry: Deconstructing the Language of Cultural Parasite
}

\author{
Wisam Kh. Abdul-Jabbar | ORCID: 0000-0001-8771-8645 \\ Faculty of Education, University of Alberta, Edmonton, Canada \\ abduljab@ualberta.ca
}

\begin{abstract}
Drawing on Michel Serres' philosophical notion of the parasite, this essay examines human responses to COVID-19 that mimic parasitic behavior and uncovers social inequalities by exploring the cultural hegemony of viral logics perpetuated by the media. How can Serres' notion of the parasite help us reconfigure structural inequalities experienced during the COVID-19 pandemic? First, the essay examines the viral logic of internalization, which seeks to normalize, if not appropriate, the impact of the pandemic through the rhetoric of togetherness. This particular viral logic induces people to internalize the coronavirus pandemic's illusion as a crisis shared equally by all. The essay argues that this viral logic of internationalization resonates with the French philosopher's parasite logic, which, in Serres's words, "expresses a new epistemology, another theory of equilibrium." Second, this study examines the viral logic of correlation, which designates certain marginalized cultural groups as infected, and therefore regarded and (mis)treated like the virus itself. This blame-game behavior mimics the parasite's violation of the host's chain of order and the creation of a new order that is self-serving. Hence, the parasite becomes, according to Serres, "an interruption, a corruption, a rupture of information." The essay argues that although mimicry becomes the theatre of cultural inequality that dominates communication for the parasitic operator, both viral logics of parasitic mimicry eventually slip into mockery.
\end{abstract}

\section{Keywords}

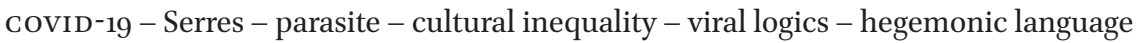


This essay examines how Michel Serres' notion of the parasite enables us to reconfigure structural inequalities exposed by the current COVID-19 pandemic. Serres' metaphor of the parasite can be used to delve into the paradoxical semantics of communication and to understand how mimicry, as a characteristic trait of the parasite, informs human relationships. Serres notes that "I don't know if mimicry is entirely parasitic, but it is a necessary trick for the robber, the stranger, the guest."1 This study picks up from Serres' question to negotiate the presence and cytopathic impact of the parasitic mimicry embedded in specific viral logics in the COVID-19 situation. I use the term parasitic mimicry to suggest a twofold viral logic: a process of correlation in which marginalized groups are portrayed as dependents whose existence mimics that of a parasite, and a process of mimicry as internalization marked by repetitive normalization. Serres' account of the parasite is challenging in part because it is presented, at least to me, as almost inescapable. The parasite is everywhere, in every relation. This phenomenon makes it difficult to mobilize critically against certain forms of apparently parasitic relation, and this difficulty helps rather than hinders the process of exploitive mimicry. That said, the parasite has a positive significance for Serres, as well as a negative one. This essay, therefore, instrumentalizes Serres' account of the parasite to address the pandemic and its unequivocally ambivalent, if not sinister, socio-political implications.

Serres' notion of the parasite has three semantic distinctions: "a biological parasite ... a social parasite ... and 'noise' or 'interference' within a system (static on the radio). These three meanings enable Serres to incorporate the natural, the social, and the semiotic into a single (albeit) complex network of interrelation."2 Accordingly, parasites can be biological, social, or communicational; in exploring Serres' notion of the parasite as a postcolonial agency, Pramod Nayar suggests "a fourth - the cultural." The cultural parasite is "not necessarily the mere presence of an Indian or a Bangladeshi in London or New York. I see the cultural parasite as an event during which Third World cultural artifacts ... interrupt the cultural narrative of London or New York and

1 Michel Serres, The Parasite, trans. L.R. Schehr (Baltimore: Johns Hopkins University Press, 1982), 202.

2 Peter Remien, "Jonson's Universal Parasite: Patronage and Embodied Critique in 'To Penshurst'," Studies in Philology 111, 2 (2014): 26o.

3 Pramod K. Nayar, "The Transnational Indian Novel in English: Cultural Parasites and Postcolonial Praxis," in Imagined Identities: Identity Formation in the Age of Globalization, ed. Gönül Pultar (Syracuse: Syracuse University Press, 2014), 24. 
generate change." ${ }^{4}$ However, in this study, the parasite is not a cultural representation of the non-Western but an unhappy intruder whose cytopathic mimicry unpleasantly reinforces the demonization of certain marginalized groups and internalizes a sense of forced symbiosis to an unfair communicational system of exchange. This study addresses the following questions: how does the CoviD-19 situation help us better understand Serres' social and communicational aspects of the notion of the parasite? How does Serres' notion of the parasite help us reconfigure dominant viral logics? How does the damaging impact of the coronavirus expose a rhetoric of parasitic mimicry that has come to dominate the media and different forms of culture and knowledge?

\section{$2 \quad$ Michel Serres and Communication Theory}

Serres's works have not enjoyed the same popularity or influence as many of his French contemporaries. This essay is partly prompted by this negligence; as Steven D. Brown notes: "Serres has by any conceivable criterion been far less influential than peers such as Foucault and Deleuze. Although he has been and remains a prodigious author (averaging a book a year for the past four decades), only a small minority of his work has been translated from his native French." ${ }^{5}$ Alan D. Schrift likewise points out that Serres' work "is virtually ignored by American Continental philosophers ... The English-speaking philosophical community's relative indifference and inattention to Serres is reflected as well by its failure to note ... some of the most influential philosophers of the last two decades of the twentieth century." 6 This may be because French philosophers generally believe that language is more than simply a means of communication. For writers such as Serres, Jacques Lacan, or Gilles Deleuze, "language is the very material on which to experiment for any argument to gain some meaning." ${ }^{7}$ However, what sets Serres apart from other twentieth-century philosophers is his argument that our modern times are inflected by the crisis of negligence of a moral and philosophical engagement with the world: "For

4 Ibid., 25 .

5 Steven D. Brown, "In Praise of the Parasite:The Dark Organizational Theory of Michel Serres", Informática na educação: teoria \& prática 16, 1 (2013): 92.

6 Alan D. Schrift, Twentieth-Century French Philosophy: Keys, Themes, and Thinkers (Oxford: Blackwell, 2006), 76 .

7 Bruno Latour, "The Enlightenment without the Critique: A Word on Michel Serres' 'Philosophy', in Contemporary French Philosophy, ed. A. Phillips Griffiths (Cambridge: Press Syndicate, University of Cambridge, 1987), 96. 
Michel Serres, the world is the most neglected of the objects of philosophy." Serres further believes that philosophy is responsible for its aversion to engaging with worldly concerns.

Serres' contribution to communication theory can be seen as a process of verification by negation. In other words, it is defined by what hinders and not what helps communication. For Serres, communication initiates a process of noise elimination: "To hold a dialogue is to suppose a third man and to seek to exclude him; a successful communication is the exclusion of the third man."9 In effect, Serres clearly states: "Eliminate the parasites from the channel so the message can go through as best it can. The imperative of purge. Thus exclude the third, the Demon, prosopopoeia of noise."10 This process of disavowal expunges an interference: "This third space - personified as the parasite - is essential to thinking communication and transformation in systems. Parasitism operates through the logic of taking without giving or 'abuse value."." Serres directly refers to the "third man" as a parasite ${ }^{12}$; dialogical communication aims to eliminate that "third man" or "parasite" to ensure the act of reciprocity in communication. Serres explains that when there are "two stations," there is "a channel ... They ex-change messages. If the relation succeeds, it is perfect, optimum, and immediate; it disappears as a relation. If it is there, if it exists, that means that it failed. It is only mediation. Relation is nonrelation. And that is what the parasite is."13 He also argues that, for instance, if the two interlocutors in a Platonic dialogue fail to exclude the "third man," the latter takes, like a parasite, serving as "the means of turning the dialogue toward asymmetry and toward one-directional movement."14 The parasite aims to enter the channel and either disrupt or diversify the exchange of thoughts, producing a state of semantic inadequacy. The effort to identify and exclude this parasite, which is proverbially referred to as the elephant in the room, is the burden of communication theorists.

8 Bsaithi Omar, Land and Mind: Kenneth White's Geopoetics in the Arabian Context (Cambridge: Cambridge Scholars Publishing, 2008), 42.

9 Michel Serres, Hermes, Literature, Science, and Philosophy, ed. Josue V. Harari and David F. Bell (Baltimore: Johns Hopkins University Press, 1982), 67.

10 Serres, The Parasite, 56.

11 Brown, "In Praise of the Parasite," 83.

12 Serres, The Parasite, 109.

13 Ibid., 79.

14 Ibid., 204. 


\section{Serres' Notion of the Parasite: the Art of Mimicry}

Drawing on Serres' account of the parasite is potentially an approach that provides an analysis of the COVID-19 pandemic situation. In addition, this essay suggests that considering the pandemic may help us understand Serres' conception of the parasite, not necessarily in a new way or in a new light; it mainly serves to illustrate the meaning of the parasite for Serres in relation to COVID-19. The essay provides a reflection on the significance of the notion of the parasite to understand the inequalities exposed by the pandemic.

Serres uses the metaphor of a parasite not necessarily to refer to a nonhuman entity but to reflect on how we behave when forming relationships or encountering different realities. From an etymological angle, the word parasite comes

... from the Latin term animalis - meaning "with soul" - it usually refers to the members of the kingdom Animalia, to which Homo sapiens belongs. Does this mean, then, that humans can be parasites? ... the definition certainly seems to point in this direction. ${ }^{15}$

I invoke the term parasitic because it "involves some kind of moral judgment ... that there is something bad or anomalous or not 'ethical' about such discourse." 16 The parasite is, by definition, a creature that is "somehow immorally sponging off the host."17 Similarly, Josue V. Harari and David F. Bell argue that the parasite is "an overbearing guest, an organism that lives off another organism." ${ }^{18}$ In An Introduction to Parasitology, Bernard E. Matthews defines parasites as "animals that live for an appreciable proportion of their lives in or on another organism, their host, are dependent on that host and benefit from the association at the host's expense."19 Other studies have suggested a connection between humans and parasites, or humans as parasites. ${ }^{20}$ Likewise,

\footnotetext{
15 Anders M. Gullestad, "Literature and the Parasite", Deleuze Studies 5, 3 (2011): 305.

16 John R. Searle, "Reiterating the Differences: A Reply to Derrida", Glyph 1 (1977): 205.

17 Ibid.

18 Josue V. Harari and David F. Bell, introduction to Hermes, Literature, Science, and Philosophy, by Michel Serres, ed. Josue V. Harari and David F. Bell (Baltimore: Johns Hopkins University Press, 1982), xxxix.

19 Bernard E. Matthews, An Introduction to Parasitology (Cambridge: Cambridge University Press, 1998), 12.

20 Luis P. Villarreal, "On Viruses, Sex, and Motherhood", Journal of Virology 71, 2 (1997): 859-65; Gullestad, "Literature and the Parasite".
} 
Arthur Kroker and David Cook explain how Serres advantageously uses the semantic ambiguity of the word parasite in French,

... which extends out into a number of meanings. From biology, he takes the notion of the parasite as both a harmful and destructive operator ... in the immune system ... and yet on the other side, all health depends upon the activities of other parasitical bodies which bring back to balance the flow of power in the biological system. ${ }^{21}$

Most importantly, Serres' work points out how the presence of the parasite determines the nature of the relationship between the affected and inflicted sides: "The parasite is an exciter," 22 compelling its host to change "its nature, its form" and its "states differentially." 23 He notes that the parasite introduces a world of position and dominance: "to play the position or to play the location is to [and] dominate the relation ... that is the meaning of the prefix para-in the word parasite: it is on the side, next to, shifted; it is not on the thing, but on its relation." ${ }^{24}$ Assertively, in an interview with Raoul Mortley, Serres explains that "the parasite is a creature which feeds on another, but gives nothing in return. There's no exchange, no balance sheet to be drawn-up: there's no reciprocity in the relationship, which is one-dimensional."25 Moreover, Laura Walls notes that the essence of Serres' relationship ethics is to "make a new pact with our old enemy, the world," 26 and that world is bound by dynamic relationships in which the parasite forms the only constant variable: "there is no system without parasites. This constant is a law." 27

Serres' approach invites us to look at ways to identify and co-exist with what is perceived to be parasitic:

The widespread understanding of parasites as worthless, degenerate creatures ... Even though later scientists have realised that such a view is extremely simplified, bordering on the outright erroneous, they have not

21 Arthur Kroker and David Cook, The Postmodern Scene: Excremental Culture and HyperAesthetics (Montreal: CTheory Books, 2001), 193.

22 Serres, The Parasite, 191.

23 Ibid.

24 Ibid., 38.

25 Raoul Mortley, "Chapter III: Michel Serres", in French Philosophers in Conversation: Levinas, Schneider, Serres, Irigaray, Le Doeuff, Derrida (New York: Routledge, 1991), 57.

26 Laura Walls, "Michel Serres on Thinking a Multiple Earth", Interdisciplinary Studies in Literature and Environment 4, 2 (1997): 114.

27 Serres, The Parasite, 12. 
managed to shake off the very deeply ingrained negative associations the term still brings to mind. ${ }^{28}$

The parasite is viewed as an intrusive partner that "presents itself in a negative guise ... a malfunction, an error, or a noise within a given system. Its appearance elicits a strategy of exclusion ... the parasite as an unhappy addition that it would be best to expel. ${ }^{29}$ Accordingly, for the parasite to survive expulsion, it needs to mimic its host in order to avoid rejection:

To avoid the unavoidable reactions of rejection, exclusion, a (biological) parasite makes or secretes tissue identical to that of its host at the location of contact points with the host's body. The parasited, abused, cheated body no longer reacts; it accepts; it acts as if the visitor were its own organ. It consents to maintain it; it bends to its demands. The parasite plays a game of mimicry. It does not play at being another; it plays at being the same. ${ }^{30}$

Serres, therefore, views mimicry as characteristic of parasitic behavior. The parasite engages in mimicry in the sense that it masks its otherness and "plays at being the same" - that is, it plays at being the same as its host. Then this sense of mimicry, which manifests itself in different forms and shapes among different species, duplicates itself afterward internally as the parasite starts making copies of itself.

By mimicking others, we love them and hate them; but, in addition, ever since the Greek dawn, we have also imitated things, and the same conclusions must be drawn from this: we serve them and destroy them. Therefore, the same ethics applies to things as to men: as well as the latter, our knowledge must preserve the world, and serve, as well, toward the end of the conflict that opposes us to this world. ${ }^{31}$

It is a self-serving mechanism that is ostensibly servile to the host's interests. It infiltrates the system by creating a doppelganger, a biological lookalike that deludes the other as self. Mimicry is the most common and lethal characteristic

28 Gullestad, "Literature and the Parasite", 304.

29 Harari and Bell, introduction to Hermes, Literature, Science, and Philosophy, xxvi.

30 Serres, The Parasite, 202.

31 Michel Serres, Variations on the Body, trans. R. Burks (Minnesota: University of Minnesota Press, 2012), 101. 
of viruses such as COVID-19; once it enters, "the invader makes copies of itself and multiplies throughout your body." 32 Its ability to use the host in order to replicate itself ensures its dominance:

Once the virus' RNA has entered a cell, new copies are made and the cell is killed in the process, releasing new viruses to infect neighboring cells in the alveolus. This process can occur initially without a person being aware of the infection, which is one of the reasons Covid-19 has been able to spread so effectively.33

In effect, the relationship between COVID-19 and its host matches the classical definition of a parasite: "the parasite befouls someone else's inside(s), and in so doing, appropriates what was not its own to begin with."34 I argue, therefore, that COVID-19 has infected human relationships with the universal characteristic of mimicry.

The general perception that has been promoted in the media is the deliberate re-presentation of COVID-19 as a great equalizer and leveler of social, ethnic, and class divisions. The new viral logic is that since the virus does not discriminate or recognize racial or religious boundaries, we are all equally vulnerable:

Rather than trying to cover it all up with pithy sayings - rather than trying to sweep these divides under the rug with platitudes like 'we're all in this together' - we should use this moment as an opportunity to take a hard look at the broken systems that perpetuate inequality: education, health coverage, distribution of opportunity and wealth, to name a few. ${ }^{35}$

32 H.D. Bhargava, “Coronavirus: What Happens When You Get Infected?" WebMD, 28 May 2020, https://www.webmd.com/lung/coronavirus-covid-19-affects-body\#1. Accessed 03/07/2020.

33 Nick Routley, "Visualizing What COVID-19 Does to Your Body", Visual Capitalist, 10 April 2020, https://www.visualcapitalist.com/visualizing-what-covid-19-does-to-your -body/. Accessed o3/o7/2020.

34 Isabella Winkler, "Love, Death, and Parasites", in Mapping Michel Serres, ed. Niran Abbas (Ann Arbor: University of Michigan Press, 2005), 228.

35 Mya Guarnieri, "Stop Saying 'We're All In This Together.' You Have Money. It's Not the Same", The Washington Post, 18 April 2020, https://www.washingtonpost.com/outlook/ 2020/04/18/coronavirus-retail-jobs-inequality/. 
The repeated statement "we are all in this together" is a perfect example of viral logic. Mercedes Bunz explains that viral communication does not spread by chance but is supported by certain rules of engagement that "accelerate its viral aspect." 36 The first rule of viral communication is that it addresses "the viewer directly thereby promising a personal merit." ${ }^{37}$ Second, it starts slowly, "based on links, being embedded, republished and linked to, its distribution accelerated slowly from one individual to another."38 Third, it can spread rapidly through repetition: "Thus we can say, the viral logic of the digital public gathers masses that aren't just spread territorially but also in time, and repetition is its drive." ${ }^{39}$ However, its most common and lethal attribute is reflected in its capacity to infiltrate and spread disguised as common sense.

I argue here that this CoviD-19-related viral logic is what Serres refers to as noise. In communication theory, the parasite "is responsible for the transmission of messages between points, and yet it is, itself, the static in the line which impedes the communication." 40 To be accurately characterized as intrusive, parasites require noise: "Ideally, communication must be separated from noise. Noise is what is not communicated; it is just there as a kind of chaos, as the empirical third element of the message, the accidental part, the part of difference that is excluded." ${ }^{41}$ In fact, from Serres' point of view, parasites are noise. Noise is external to clear communication, and the parasite's task is to transmit noise into the communicational channel. This is how it dominates the transmission and dictates its own signals. In other words, with Serres, we are presented with a model of communication in which

... we have three elements: a message, a channel for transmitting it, and the noise, or interference, that accompanies the transmission. Noise calls for decipherment; it makes a reading of the message more difficult. And yet without it, there would be no message. There is, in short, no message without resistance. What Serres initially finds intriguing about noise (rather than the message) is that it opens up such a fertile avenue of reflection. ${ }^{42}$

36 Mercedes Bunz, The Silent Revolution: How Digitalization Transforms Knowledge, Work, Journalism, and Politics Without Making Too Much Noise (London: Palgrave Macmillan, 2014), 89 .

37 Ibid.

38 Ibid.

39 Ibid.

$40 \quad$ Kroker and Cook, The Postmodern Scene, 193.

41 John Lechte, Fifty Key Contemporary Thinkers: From Structuralism to Post-Humanism (London: Routledge, 1994), 83 .

42 Ibid. 
I identify Serres' concept of noise within the COVID-19 situation with the viral logics often lost in translation, misunderstood, or caused misunderstanding. The aim of viral logics is not to deliver but to spread. The message is delivered incomplete, interrupted, and logical when it is often a logical fallacy.

For Serres, noise is inseparable from communication: "we know no system that functions perfectly, that is to say, without losses, flights, wear and tear, errors, accidents, opacity - a system whose return is one for one." 43 The art of separating noise from communication defines Serres' philosophy. Is it possible to create a communication passage devoid of noise and, therefore, of viral logics? Serres believes it is not, as all systems are infested with noise. Thus, the challenge of philosophers is to separate knowledge from noise and identify parasitic, viral logics that hide within channels of communication. This noise becomes internalized when it remains undetected. Internalization is a mental and psychological state in which ideas are unconsciously assimilated into the psyche and uncritically accepted as common knowledge. The internalized viral logics of togetherness and feel-good projects are a good case in point. For instance, projects intended to offer public relief proliferated but have largely been promoted by celebrities who are clearly well sheltered or at least do not share the vulnerability experienced by less fortunate groups:

In an attempt to lift spirits and show solidarity with the general public, a cadre of 21 high-profile celebrities joined forces to sing "Imagine" by John Lennon. Featured in the montage, which was shared widely across social media, were the likes of Gal Gadot, Will Ferrell, Jimmy Fallon, Mark Ruffalo, Natalie Portman, Amy Adams, Kaia Gerber, Kristin Wiig, and Zoë Kravitz. ${ }^{44}$

Such videos were criticised as ineffectual and inconsiderate of those who are facing unemployment and whose lives are at risk. These moments are examples of parasitic noise, "an operator that interrupts a system of exchange. The abusive guest partakes of the host's meal, consumes food, and gives only words, conversation, in return." ${ }^{25}$ In this context, for Serres, the media's promotion of togetherness acts in a parasitic manner, downgrading the tragic effects of the coronavirus into a travesty of social equality: "Real production is undoubtedly

43 Serres, The Parasite, 12-13.

44 Hanna Lustig, “24 Times Celebrities Have Been Completely Unrelatable during Quarantine”, Insider, 24 April 2020, https://www.insider.com/celebrities-quarantine-social -media-distancing-have-been-completely-unrelatable-in-2020-4. Accessed o4/o7/202O.

Harari and Bell, introduction to Hermes, Literature, Science, and Philosophy, xxvi. 
rare, for it attracts parasites that immediately make it something common and banal. Real production is unexpected and improbable; it overflows with information and is always immediately parasite." ${ }^{\text {"6 }}$ Accordingly, such mottos of togetherness coalesced into a viral logic that fosters a sense of belonging that viewers then internalize.

The media exploit mimicry and transform it into a hegemonic power by capitalizing on the instinctive human desires to emulate and to belong: "Our genetic tendency to engage in mimetic behavior is why purchaser citizens passively internalise commercial codes without reflecting critically about the unrealistic and exploitative nature of the images that we consume daily."47 The media establishment has, therefore, successfully developed a social consciousness of internalizing mimesis as a normative behavior: "In the context of the manufacturing and transmission of commercial simulacra via the corporate media, Serres elucidates that the force of mimesis explains why so many individuals desperately strive to "keep up with the Joneses." 48 The parasite induces the host to internalize a system of unequal exchange by mimicking the host's life by assuming the same role, history, and social communication. If the noise passes undetected, it becomes viral, and the parasite dominates the relationship: "Noise is parasitical, like interference, it follows the logic of the parasite, a very tiny thing, an insufficient reason, a cause without consequence at times, which may vanish to the left of the dovetail."49 Repetitive reminders urging people to "Stay Home" do not suggest a sense of togetherness but refer to an existing disparity seemingly imperceptible to the proclaimer. John Eligon and colleagues, for example, have pointed out that the coronavirus has infected and killed African Americans in the United States in disproportionately high numbers. Public health researchers refer to "entrenched inequalities in resources, health and access to care." ${ }^{n 0}$ The released data and statistics from different sources "are alarming enough that policymakers say they must act immediately to stem potential devastation in black communities."51 For instance, "African-Americans account for more than half of those who have tested

46 Serres, The Parasite, 4.

47 Keith Moser, The Encyclopedic Philosophy of Michel Serres: Writing the Modern World and Anticipating the Future (Augusta: Anaphora Literary Press, 2016), 37.

48 Ibid., 36 .

49 Michel Serres, Genesis, trans. Genevieve James and James Nielson (Ann Arbor: University of Michigan Press, 1995), 57.

50 John Eligon et al., "Black Americans Facing Alarming Rates of Coronavirus Infection in Some States", The New York Times, 7 April 2020, https://www.nytimes.com/2020/04/o7/ us/coronavirus-race.html. Accessed o3/o7/2020.

$5^{1} \quad$ Ibid. 
positive and 72 percent of virus-related fatalities in Chicago, even though they make up a little less than a third of the population."52 The viral logic of togetherness has reduced these existing structural inequalities into an internalized illusion of a shared crisis that mimics parasitic behavior, in a process similar to what Serres calls the logic of the parasite, in which a sense of false equilibrium is being enforced:

The parasite invents something new. It intercepts energy and pays for it with information ... These would be two ways of writing the new contract. The parasite establishes an agreement that is unfair, at least in terms of previous accounting methods; it constructs a new balance sheet. It expresses a logic that was considered irrational until now, it expresses a new epistemology, another theory of equilibrium. ${ }^{53}$

The best way to break this hegemonic relationship is to identify its viral logic and its internalizing mechanism: "We must be fully mindful of how this crisis is amplifying the challenges and disadvantages faced by people living on the margins of society." ${ }^{\prime 5}$ Robert Reich, for instance, explains how COVID-19 has drawn our attention to an existing class division that has deepened and exposed inequality in liberal societies. ${ }^{55}$ Of course, this is not to say that viral logic discriminates only based on class. Other forms of inequality and exclusion are part and parcel of the process. Unpacking the dominant psychology behind the viral logic of togetherness that unkindly disregards class differences and indirectly diminishes the suffering of the underprivileged is one of the main steps towards recovery: "As the virus continues to burn its way through our population, it is revealing some unpleasant truths about the way we live. In that regard, we are experiencing very different impacts - different pandemics, so to speak. In that regard, we are most certainly not all in this together."56 Hence, the repetitive message of "Stay Home," dominant in North America,

\footnotetext{
$52 \quad$ Ibid.

53 Serres, The Parasite, 51.

54 Marie-Claude Landry, "Statement - Inequality Amplified by COVID-19 Crisis", Canadian Human Rights Commission, https://www.chrc-ccdp.gc.ca/eng/content/statement-inequal ity-amplified-covid-19-crisis. Accessed o3/o7/2020.

55 Robert Reich, "COVID-19 Pandemic Shines a Light on a New Kind of Class Divide and Its Inequalities", The Guardian, 26 April 2020, https://www.theguardian.com/commentis free/2020/apr/25/covid-19-pandemic-shines-a-light-on-a-new-kind-of-class-divide-and -its-inequalities. Accessed 10/o7/2020.

56 Dan Dunsky, "When it Comes to COVID-19, We're Not All In It Together", TVOntario, 28 May 2020, https://www.tvo.org/article/when-it-comes-to-covid-19-were-not-all-in-it -together. Accessed 10/07/202O.
} 
becomes an irritating and derisive hourly reminder for those whose jobs do not allow them the luxury of staying home.

Serres' notion of the parasite can be, and is, applied to human beings as well. Sidelined groups are often depicted as, and even accused of, being parasitic off the mainstream: "Serres recognizes that each life form, including humans, must inflict a certain amount of violence upon the earth for the sake of selfpreservation." ${ }^{57}$ Parasitic mimicry is, therefore, a way of being in the world that underscores the inescapable desire to dominate. It operates in the form of a viral logic of correlation by assuming a reciprocal relationship between two equally parasitic states. The blame game, for instance, exemplifies the viral logic of correlation. President Trump insisted on calling the coronavirus a "Chinese virus," which serves as a microcosm of how, driven by fear and anxiety, people worldwide have been exchanging this insidiously parasitic use of the Other as a figurative cell on which to feed. By this process, the coronavirus situation has paradoxically become an excuse for vandalism, social inequality, and discrimination. For Serres, violence is one of the common attributes of the parasite: "Serres' philosophy is first of all a reflection on violence, on what violence may or may not achieve." 58 The parasite violates the host's chain of order creating a new order that is self-serving, and thus becomes "an interruption, a corruption, a rupture of information ... who has the last word, who produces disorder and who generates a different order." 59 This parasitic trajectory correlates well with the blame game, which engenders a new order through a corruption of information that mutates into a viral logic.

One such example of how parasitic mimicry functions through correlation can be seen in India, as Amir Ali has noted that "Islamophobia has been transposed onto the coronavirus issue" 60 in the wake of a clash between Hindu nationalists and the Muslim minority in India. Authorities traced cases of COVID-19 to a Muslim missionary group that held its annual conference in Delhi in early March, and health officials were tracking down people who might have been in contact with the participants. Since then, "tweets with

57 Julian Yates, "The Gift Is a Given: On the Errant Ethic of Michel Serres", in Mapping Michel Serres, ed. Niran Abbas (Ann Arbor: University of Michigan Press, 2005), 205.

$5^{8}$ Latour, "The Enlightenment without the Critique", 91.

59 Serres, The Parasite, 3.

6o Billy Perrigo, "It Was Already Dangerous to Be a Muslim in India. Then Came the Coronavirus", Time, 3 April 2020, https://time.com/5815264/coronavirus-india-islamo phobia-coronajihad/. Accessed 10/07/2020. 
the hashtag \#CoronaJihad have appeared nearly 300,ooo times and potentially seen by 165 million people on Twitter."61 The combination of racial tension with the rise of Covid-19 left thirty-six Muslims dead. In times that call for human solidarity against a dangerous virus, vilifications, and attacks on Muslims, supported by bigoted statements that encouraged religious hatred, were equally virulent. Such rhetoric demonstrates patristic mimicry, as Muslims are portrayed as parasites according to the viral logic of correlation. Along the same lines, Arjun Appadurai has noted that "One of the key features of anti-Muslim sentiment in India for quite a long time has been the idea that Muslims themselves are a kind of infection in the body politic ... So there's a kind of affinity between this long-standing image and the new anxieties surrounding coronavirus." ${ }^{2}$ The coronavirus wave has unleashed other mental, behavioral, and ethical waves that are equally viral and equally devastating. Khalid Rasheed, the chairman of the Islamic Center of India, has noted that the viral logics provoked by COVID-19 are similarly disturbing and may outlive the pandemic itself: "Coronavirus may die, but the virus of communal disharmony will be hard to kill when this is over."63 In effect, the traumatic experience of COVID-19 demonstrates how a coronavirus-induced event mimics a parasitic behavior, which creates a new space, the semblance of a viral logic. In fact, one of the by-products of the advent of late-nineteenth-century parasitology is the creation of "a new space ... a space later to be inhabited by those no longer counted as fully human and which could therefore legitimately be exterminated."64 The Guardian reports, for instance:

Muslims have now seen their businesses across India boycotted, volunteers distributing rations called 'coronavirus terrorists', and others accused of spitting in food and infecting water supplies with the virus. Posters have appeared barring Muslims from entering certain neighbourhoods in states as far apart as Delhi, Karnataka, Telangana, and Madhya Pradesh. ${ }^{65}$

$61 \quad$ Ibid.

62 Ibid.

63 Jeffrey Gettleman, Kai Schultz, and Suhasini Raj, "In India, Coronavirus Fans Religious Hatred", The New York Times, 12 April 2020, https:/www.nytimes.com/2020/04/12/world/ asia/india-coronavirus-muslims-bigotry.html. Accessed ०3/o7/2020.

64 Anders M. Gullestad, "Parasite", Political Concepts, 2012, https://www.politicalconcepts .org/anders-m-gullestad-parasite/. Accessed 22/07/2020.

65 Hannah Ellis-Petersen and Shaikh Azizur Rahman, "Coronavirus Conspiracy Theories Targeting Muslims in India”, The Guardian, 13 April 2020, https:/www.theguardian.com/ world/2020/apr/13/coronavirus-conspiracy-theories-targeting-muslims-spread-in-india. Accessed 22/07/2020. 
The Hindu-Muslim tension provoked by the Covid-19 situation mimics a parasitic behaviour that infects the social fabric with false inductive viral logic that validates mimicry: "Did members of the Tablighi Jamaat [Muslim missionary group] behave recklessly? Yes. Do all of India's 200 million Muslims bear responsibility for their behaviour? No."66

To wage war on what is considered unclean and alien is to reduce it to the status of a parasite: "Serres thus imagines a 'parasite' ... [as] an abusive guest at the table of communication, renews a conversation which would otherwise grow stale by posing a topic that has nothing whatsoever to do with what has been said before", 67 or going on now. The parasite, therefore, is a producer of false viral logics and operates accordingly. What defines the viral logic of the parasite is a complete act of seamless mimicry: "an animal who lives off another without the other even suspecting it." ${ }^{68}$ In the parasitic world, mimicry ensures survival, if not mere existence. This act of mimicking becomes viral not because it is clearly false, but because it has a semblance of logic that can pass undetected and is therefore misleading: "The parasitic foreign body makes a home for itself on the inside, where it is kept in secret as part of the host." ${ }^{\prime 9}$ Serres wonders if this attribute is the parasite's most universal characteristic: "I don't know if mimicry is entirely parasitic," he states, only to affirm that "it is a necessary trick for the robber, the stranger, the guest."70 The parasite, in this case, is a manipulator of political power. Such viral logics have mimicked parasites as they target and antagonize vulnerable marginalized groups. Neal Boortz, a media figure with over two hundred thousand followers on Twitter and who hosted a widely syndicated radio talk show, posted the following comment on Twitter: "You think Covid-19 is bad? Give me a break. Wait until Muslims hit critical mass in America. You'll look back on these times fondly."71 This is an instance of correlation in which mimicry slips into mockery, and the viral logic becomes absurd. Perhaps, then, the only way to

66 Mehdi Hasan, “The Coronavirus Is Empowering Islamophobes - but Exposing the Idiocy of Islamophobia", The Intercept, 14 April 2020, https://theintercept.com/2020/04/14/ coronavirus-muslims-islamophobia/. Accessed o3/o7/2020.

67 Eric Charles White, "Negentropy, Noise, and Emancipatory Thought", in Chaos and Order: Complex Dynamics in Literature and Science, ed. N. Katherine Hayles (Chicago: University of Chicago Press, 1991), 268.

68 Michel Serres, Michel Serres with Bruno Latour: Conversations on Science, Culture, and Time, trans. Roxanne Lepidus (Ann Arbor: University of Michigan Press, 1995), 134.

69 Winkler, "Love, Death, and Parasites", 231.

70 Serres, The Parasite, 202.

71 Boortz, Neal. "You think Covid-19 is bad? Give me a break. Wait until Muslims hit critical mass in America. You'll look back on these times fondly", Twitter, 1 April 2020, https:// twitter.com/talkmaster/status/1245443387068686336?lang=en. Accessed ०3/o7/2020. 
expel this "viral illogic" is to mimic its absurdity, as demonstrated in Johana Bhuiyan's response to Boortz: "Sweetie everyone's already washing their hands five + times a day, covering their face, not shaking hands + avoiding bars. Not only are we already here, you're all Muslim. Salam brother."72 Serres himself, it seems, recognizes the link between parasitic behavior and the possibility of the rise of the laughable: "depending on the circumstances, being slavish, parodic, a parasite, a copyist. One may well wish to become a copyist or to live as a parasite, it's even a comfortable existence. One may get a laugh from a bit of parody, as well."73 To mimic is, therefore, to dominate via association. It is a disquieting parasitic behavior that dictates its own rules of engagement by creating an infected assemblage that can be blamed and cleaned if not exterminated. In other words, parasitic mimicry takes the shape of a deviated social consciousness:

... mimesis often frames social consciousness in addition to fostering a sense of belonging to a given group ... Serres observes that not only does mimesis play a major role in delineating group boundaries, but this genetic trait also forms the basis for many different types of exclusion, ostracism, prejudice, and persecution. ${ }^{74}$

The blame game betrays a viral social consciousness that is inherently selfdestructive because it initiates a group boundary of which only one side survives.

Irony creeps in when the seemingly triumphant human group who initiated the blame game unknowingly seals its own destiny, as Serres explains: "Death to the parasite, someone says, without seeing that a parasite is put to death only by a stronger parasite. ${ }^{75}$ The intrusive viral logic of correlating Muslims in the USA or India with coronavirus activities descends into mockery because, ironically, the outcome becomes contrary to what is expected: "Here is the great irony: While anti-Muslim bigots have tried to use the coronavirus to smear and demonise Muslims, the pandemic itself has exposed the ridiculousness of

72 Johana Bhuyian, 'Sweetie everyone's already washing their hands five + times a day, covering their face, not shaking hands + avoiding bars. Not only are we already here, you're all Muslim. Salam brother', Twitter, 1 April 2020, https://twitter.com/JMBooyah/status/ 1245537894732726273. Accessed ०3/07/2020.

73 Serres, Genesis, 103.

74 Moser, The Encyclopedic Philosophy of Michel Serres, 37.

75 Serres, Genesis, 131. 
anti-Muslim bigotry."76 Even so, this viral logic, again like any parasitic activity, does not pass unnoticed, nor is it without its own mishaps. Like Khalid Rasheed, Mehdi Hasan believes that this parasitic legacy that will outlive the pandemic is even more alarming than the virus itself: "We may defeat the CoviD-19 virus in the months ahead, but it will take much longer to defeat the disease that is Islamophobia." ${ }^{77}$ This expected outcome resonates with Serres' understanding of the aftermath of a parasitic event: "The work of the parasite changes systems ... or else the work of this parasitic interference is nought ... As it goes: you will never again see the carrier, the factor. Even the opportunity is erased, the vector vanishes. The cause passes, the effect remains."78 It is worth noting here that the World Health Organization was particular about vilifying racial or otherwise labeled groups within the COVID-19 situation:

Social stigma in the context of health is the negative association between a person or group of people who share certain characteristics and a specific disease. In an outbreak, this may mean people are labelled, stereotyped, discriminated against, treated separately, and/or experience loss of status because of a perceived link with a disease ... The current Covid-19 outbreak has provoked social stigma and discriminatory behaviours against people of certain ethnic backgrounds as well as anyone perceived to have been in contact with the virus. ${ }^{79}$

Parasitic mimicry through correlation is a relationship that is evoked only to be dominated, if not vanquished. Addressing the sociopolitical implications, Jonathan Xavier Inda explores the prevailing rhetoric of "nativism," which dismisses immigrants as parasites posing "a threat to the general welfare of the nation." 80 Provoked by social stigma and the sociopolitics of the blame game, the viral logics of correlation slip into mockery because it is reduced to a sheer camouflage of irony and absurdity.

\footnotetext{
${ }_{7} 6$ Hasan, "The Coronavirus Is Empowering Islamophobes".

77 Ibid.

78 Serres, Genesis, 57 .

79 wно Global, "A Guide to Preventing and Addressing Social Stigma Associated with COVID-19", 24 Feb. 2020, https:/www.who.int/who-documents-detail/a-guide-to-pre venting-and-addressing-social-stigma-associated-with-covid-19?gclid=EAIaIQobChMI2Ke av9PZ6QIVFBLnCh3YAgdcEAAYASAAEgJghfD_BwE. Accessed o3/o7/2020.

80 Jonathan Xavier Inda, "Foreign Bodies: Migrants, Parasites, and the Pathological Nation", Discourse, 22, no. 3 (200o), 46 .
} 
This essay revisits Serres's concept of the parasite presented as both virus and human trait as they move towards each other, overlap and mimic each other, and infect communication in a world divided by the coronavirus with viral logics. Serres uses parasitology to identify forms that disrupt communication in order to dominate; this essay uses Serres' theoretical framework to negotiate the evasive rhetoric of the viral logics of togetherness, particularly how the notion of the parasite exemplifies the adoption of models of viral logic in relation to the reality of COVID-19. Such viral logics serve prescribed and unscrutinized objectivity that the media perpetuates through repetition. Serres' notion of the figure of the parasite, invoked to shed light on "viral logics" that promote exclusion and violence against the "other," is arguably comparable to notions of immuno-politics developed by Roberto Esposito, who writes:

The fact is that today anyone with eyes to see cannot deny the full deployment of biopolitics. From biotechnology interventions on areas once considered exclusively natural such as birth and death, to biological terrorism, to the management of immigration and more or less serious epidemics, all current political conflicts have at the center the relationship between politics and biological life. ${ }^{81}$

Like Serres, Esposito suggests that the pandemic exposed limitations of freedom. In an interview conducted via skype, Esposito comments on the parasitical relationship between the pandemic and the economy, which propagates social inequalities:

This epidemic crisis shows just how profoundly our society is marked by inequality ... It exacerbates a distinction already present in our economy between exploited workers and certain privileged groups that financially even benefit from this pandemic ... What is happening in America right now with the protests following the death of George Floyd is not merely the result of a history of racism. It is also a protest against a society that has dismantled the welfare state, social security services, and publicly available medicine. ${ }^{82}$

81 Cited in Michael A. Peters \& Tina Besley (2020) Biopolitics, conspiracy and the immunostate: an evolving global politico-genetic complex, Educational Philosophy and Theory, DOI: 10.108 o/oo131857.2020.1772026.

82 Tim Christiaens and Stijn De Cauwer. The Biopolitics of Immunity in Times of COVID-19: An Interview with Roberto Esposito. Antipode Online. (2020). https://antipodeonline .org/2020/o6/16/interview-with-roberto-esposito/. Accessed o3/o7/2020. 
In effect, COVID-19 has exposed a sociopolitical culture of deprivation, complacency and even complicity. In other words, using Serres' notion of the parasite, which deals "with the conditions for an epistemology of human relations," ${ }^{83}$ this study demonstrates how CoviD-19 has promoted and exposed a breakdown in the ethics and mimics of human relations. It illustrates how the intrusion and imposition of parasitic mimicry on communication and culture hegemonically direct and dictate our pandemic realities.

When confronted with a hazardous encounter with a parasite, Serres suggests negotiating "a contract of symbiosis" as a solution, "a method that will profit from its dynamism," simply because "we have to continue living with cancers, with germs, with evil and even violence. It's better to find a symbiotic equilibrium." ${ }^{84}$ Although symbiosis could be the ideal response to a world further fractured by a pandemic, this study demonstrates that parasitic mimicry is the current and common response that is characteristic of the CoviD-19 reality. It serves as an attempt to respond to Serres' questions, "And if the system in question were the collective as such? What relations do we really have with each other? How do we live together? What really is this system which collapses at the slightest noise? [of the parasite's]." ${ }^{35}$ How do we behave when the parasite hits? Have we successfully managed to maintain social distancing in terms of ostensibly being detached and indifferent to crises that do not affect us on the personal level? Have we developed the immunity of a desensitized herd who have survived as complicit parasites? The truism that the first step towards solving a problem is recognizing that there is one is helpful to remember here. This study examines how the current CoviD-19 reality is marked by parasitic mimicry that is perpetuated by the viral logics of internalization and correlation. The study draws attention to the invisibility and divisibility of false viral logics. It invites us to see how, in the words of Shakespeare's Othello, "the green-eyed monster which doth mock the meat it feeds on," in this case, is neither jealousy nor the coronavirus itself, but the mode of sheer human parasitic mimicry.

\section{Biography}

Wisam Kh. Abdul-Jabbar received his Ph.D. (funded by the Social Sciences and Humanities Research Council of Canada) from the University of Alberta, where he was awarded The Bacchus Graduate Research Prize for scholarly

\footnotetext{
83 Harari and Bell, introduction to Hermes, Literature, Science, and Philosophy, xv.

84 Serres, Michel Serres with Bruno Latour, 195.

85 Serres, The Parasite, 12.
} 
excellence in International and Multicultural Education. He received an M.A. from Lakehead University and another M.A. from California State University in Humanities in an interdisciplinary program. Dr Abdul-Jabbar held a postdoctoral fellowship (also funded by SsHRC) at the University of Calgary. His research considers how intercultural dialogue resonates with educational and philosophical practices and explores convergences of seemingly differing cultures. Currently, he is an adjunct professor at the University of Alberta. He is the author of Negotiating Diasporic Identity in Arab-Canadian Students Double Consciousness, Belonging, and Radicalization (Palgrave, 2019). 